\title{
Effects of Brand Familiarity, Brand Trust, and Marketing Strategies on Brand Image and Brand Attachment
}

\author{
Piyamas Suesawadwanit, Thitapa Na Ranong and Apicha Boonpattarakan
}

\begin{abstract}
The objective of this research was to investigate the effects of brand familiarity, brand trust, and marketing strategies comprising taste of food, perceived price, accessibility, and attractiveness of sales promotion on brand image and brand attachment. The data was collected from the Japanese buffet restaurants, a very popular place for Thai consumers to visit. We developed our conceptual framework and tested it using the LISREL program. Convergent validity and discriminant validity were achieved. Then, we tested the relationships among all the constructs. It was found that brand trust, accessibility, and taste of food had significant and positive effects on brand image. In case of brand attachment, taste of food, accessibility, attractiveness of sales promotion, and brand trust had significant and positive effects on brand attachment. Goodness of fit indices were found to be very satisfactory.
\end{abstract}

Keywords-Brand Attachment, Brand Familiarity, Brand Image, Brand Trust.

\section{INTRODUCTION}

Branding has become one of the most important strategies in the business world. Building a brand is considered to be a vital task for those who own a brand. The building of a brand that is recognizable may be carried out through the implementation of marketing communication. However, marketing communication itself may not be sufficient to create a strong brand. A brand itself is basically the result of a brand effort involving multiple strategies; it may be a name, a symbol, or a combination of both. However, brands are deemed to be one of the most important assets of the business who owns it. When a brand is created, all marketing tools must be utilized to make consumers aware of it, recognize it, familiar with it, trust it, perceive it to have a good image, and attach to it. If consumers perceive a brand to have a good image and attach to that brand, it will lead to intention to consume the brand more frequently [1]. Creating brand image and brand attachment is deemed to be a very significant strategy for those who own a brand. Hence, this research was aimed at investigating the effects of brand familiarity, brand trust and marketing strategies on brand image and brand attachment. The focus will be on the Japanese buffet restaurants since Thai people love Japanese food so much and there are so many Japanese buffet restaurants in Thailand. The study is well suited to focus on these restaurants.

Piyamas Suesawadwanit is with the Faculty of Business Administration, Ramkhamhaeng University, Thailand

Thitapa Na Ranong is with Alliance Pharma Company Limited, Thailand

Apicha Boonpattarakan is with the Faculty of Business Administration, Ramkhamhaeng University, Thailand

\section{LITERATURE REVIEW}

\section{A. Branding and Brand}

Branding is simply an action of creating a brand. The process involves creating a special and unique name for a product in the consumers' mind through marketing communication and other elements of marketing strategies. It also involves positioning our product in the market. Branding focuses on building a significant brand that will differentiate itself from others and, at the same time, attract consumers. Branding can develop a brand to such a point that it plays a key role in consumer mind and gains competitive advantage [2]. A brand is the result of a branding effort to create it. The American Marketing Association defines "brand" as: "a name, term, design, symbol, or any other feature that identifies one seller's good or service as distinct from those of other sellers. The legal term for brand is trademark. A brand may identify one item, a family of items, or all items of the seller. If used for the firm as a whole, the preferred term is trade name" [3]. Good brands communicate with consumers through brand stories that will play a key role in helping consumers understand the personality of a brand. A good brand must contain value and distinct characteristics that differ from other brands.

\section{B. Brand Image and Brand Attachment}

Image is the overall impression in the minds of consumers about something [4]. In analogy, brand image can be referred to as beliefs, attitudes, and impressions perceived by consumers. Brand image can be defined as the character of the brand as perceived in the mind of consumers [5]. Brand image is considered to contain a set of beliefs, ideas, and impression that a person holds regarding a particular brand [6]. Brand image normally develops over a period of time and can be perceived differently by different consumers. Studies in the past have investigated the relationships among brand image, customer satisfaction, brand awareness, perceived quality, etc. [7], [8]. In this study, brand image is referred to as an overall impression of a particular brand in the mind of consumers.

Brand attachment can be described as the emotional closeness between consumers and the brand itself. It can be defined as "the strength of the bond connecting the brand with the self" [9]. The definition of brand attachment has been extended to refer to an emotional relationship between consumers and the brand characterized by the feelings of connection, affection, and passion about the brand to the self [10]. Brand attachment was proposed to be based on the attachment theory [11]. The theory first described the relationship between infants and parents. Later, the concept has been applied to understand the emotional bond or attachment 
between consumers and any object including the brand. Attachment is basically a psychological state of mind in which strong cognitive and affective aspects can link a brand with a consumer. In this sense, a brand is perceived to be an extension of one's own self. Past research has studied the concept of brand attachment and has indicated that brand attachment may be associated with perception of fairness, pricing at a higher level, brand prominence, brand equity, etc. [12], [13], [14]. In this research, brand attachment is defined as an emotional link between consumers and the brand with regard to affection and passion.

\section{Brand Familiarity}

Brand familiarity is a construct used in the brand concept [15]. It is believed that if consumers are familiar with a brand, they will generally have knowledge about that particular brand [16]. It is contended that if consumers recognize a brand they are familiar with, they will generally prefer that brand [17]. Marketing scholars have shown that familiar brands are more noticeable, more easily recalled, and slightly favored by consumers than those that consumers are not familiar with [18]. Brand familiarity has also been defined as previous experience with the brand. Brand familiarity has been studied in the past and was found to have an influence on brand memory, consumer value, and attitude toward the brand [19], [20]. In this research, brand familiarity is defined as the awareness consumers have of a particular brand; therefore, that particular brand will be easily recognizable by consumers.

\section{Brand Trust}

Brand trust is defined as "the willingness of the average consumer to rely on the ability of the brand to perform its stated function" [21]. Brand trust is considered to be the expectation of consumers to believe in the brand's performance with some risk [22]. It is believed that brand trust is a concept. This concept will make consumers believe in the brand that it will be able to perform to the expectation it claims to be able to. Brand trust can also be described as a form of consumer confidence in the brand. Brand trust may come from past experience and previous encounter with the brand. It is basically a consumer feeling that the brand will perform to meet their consumption expectations [23]. Various studies have examined brand trust and its association with brand affect, brand quality, consumer satisfaction, etc. [22]. In this research, brand trust is referred to as consumer belief that the brand will perform what it claims to perform and this belief may arise from consumers' past experience with the brand.

\section{E. Marketing Strategies}

Taste - In general, marketing strategies as we know of consist of product, price, place, and promotion and often these four components are referred to as marketing mix. However, marketing mix has to adapt itself to correspond to each individual business which may be different from each other. The word product refers to something that has been offered for sale in the belief that it will satisfy the need of consumers. Products may include both tangible goods and intangible goods or services [6]. In this study, the focus is on the restaurant business; hence, the product will be considered to be the taste of food. The reputation of good taste through marketing communication and advertising will draw consumers to come and try. Consumers' own personal values will determine how good or bad the taste or aroma is. In order to retain customers, a good restaurant business must provide good product taste consistently. Otherwise, customers will come and visit only once and will not be coming back. Thus, it is believed that in the restaurant business, taste of food must be good and consistent. This is essential to the success of the business. It will also lead to the creation of positive brand image and brand attachment. In this research, taste is referred to as the quality of food perceived by customers.

Perceived Price - Pricing generally can create a certain image of the product or service. It is a very significant factor influencing consumers' decision making. Price is considered to be an important ingredient of marketing mix; it is the amount of money paid for a product or service [6]. Price can also be interpreted as a signal of product or service quality [24]. Perceived price is the perception of price by consumers. It includes money, time, search cost, effort, and psychological cost. Price can be used to build image and create product or service differentiation [25]. Consumers typically have a reference price, i.e., a specific range of price that is acceptable. Price has often been used to signal the quality of a product or service [26]. Studies have examined the relationships among perceived price, perceived value, perceived trust, perceived risk, etc. [27]. In this research, perceived price is referred to as the perception of price which may include various cost components, such as money, time, information search, effort, and psychological aspect, by consumers.

Accessibility - Accessibility is a term that has been used in recent times. In the retail sector including the restaurant business, the physical location is considered to be an important part of distribution channel because it will bring together customers and their product offerings. The more accessible our location is; the more consumers will be able to come and visit [28]. Accessibility is basically the ease of reaching the designated location. Accessibility is comparable to the concept of distribution channel. In the restaurant industry, accessibility may be referred to as the location of the restaurant that consumers perceive to be convenient to be reached or entered. In the traditional sense, accessibility involves satisfying consumer needs by making the product or service available to consumers at the location it is located. Department stores, discount stores, restaurants, and all other conventional retailing businesses that need a physical presence (brick and mortar stores) must be concerned with their physical location [29]. It is suggested that easy and convenient to access the physical location will gain competitive advantage over their competitors. In this research, accessibility means the ease as well as the convenience of accessing the location of the restaurant.

Attractiveness of Sales Promotion - The term promotion, the fourth aspect of marketing mix, may involve several key marketing tools, such as advertising, sales promotion, public relations, personal selling, etc. [6]. Sales promotion is a type of pull marketing strategy to attract consumers. In the restaurant business, sales promotion has become a key determinant for consumers to enter and obtain the service and food. A very popular sales promotion technique frequently used in the restaurant business is discounts which may include discounted 
prices during certain times of the day or week, reduced drink prices during certain times, offering eat-free programs on specific occasion, such as birthday, etc. Even though our sales promotion is good, we still have to make our target customers aware of it through any medium, such as placing the information on banner in front of the restaurants, giving a discount on the customers' receipts, providing a promotional card specifying the number of times the customer has visited, etc. [30], [31]. In this research, attractiveness of sales promotion is defined as the sales promotion given to potential customers that are attractive enough to draw them into the restaurants.

\section{CONCEPTUAL FRAMEWORK}

From the literature review, a conceptual framework is developed. In this study, we proposed that brand familiarity, brand trust, taste, perceived price, accessibility, and attractiveness of sales promotion will have positive effects on brand image and brand attachment. Figure 1 illustrates this conceptual framework.

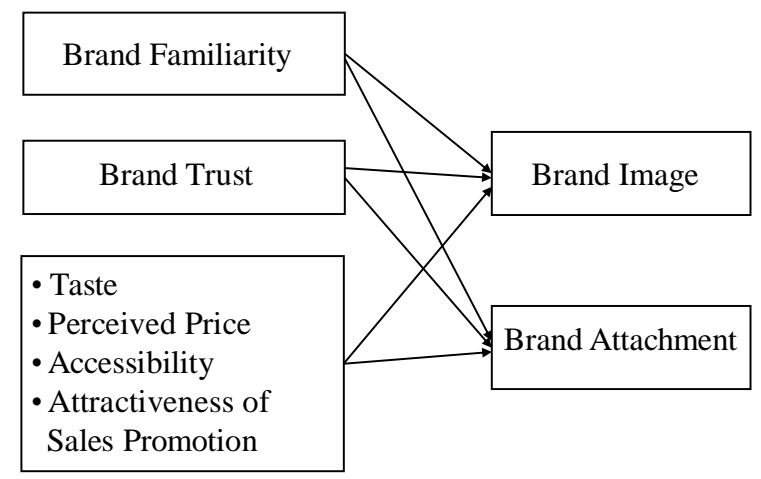

Fig. 1. The research conceptual framework

\section{Methodology}

The population of interest was customers of Japanese buffet restaurants. The researchers chose Japanese buffet restaurants because there were very popular and had numerous brands in the Bangkok Metropolitan area in Thailand and Thai people loved to visit one of these restaurants. Most brands had branches. We used purposive sampling to select four comparable restaurants that had branches and used simple random sampling to select two branches from each restaurant. We collected data from those customers who had visited the restaurants no more than twice in the past three months. Since we were planning to use SEM with LISREL program to analyze the data, we needed twenty samples per each observed variable/indicator/question. We had twenty-four indicators; hence, the sample size would be 480 . This meant we would have to collect data from 60 customers per branch. We contacted the restaurants and asked for their permissions to collect data from their customers.

Our measures were based on five point Likert scales and were adapted from existing measures as well as the definitions of the constructs. In order to perform reliability analysis, multiple items were used for each construct. A questionnaire was then developed. We then examined content validity by asking five scholars to perform the IOC (Index of Item-Objective Congruence). Those ambiguous questions were modified.
Then, a pretest was carried out with 50 samples. Data were collected and reliability analysis was performed. Cronbach's alphas were computed. All the Cronbach's alphas were above 0.7 [32]. The lowest was 0.749 and the highest was 0.964 . Most of them were above 0.8 . This meant the measures were reliable and good. Our data collection method was based on face-to-face interviews and the total number of questionnaires collected was 480 as mentioned above.

\section{ANALYSIS AND RESULTS}

First, we checked all the completed questionnaires and dropped two questionnaires because they were unusable. The usable questionnaires left for analysis were 478 . The sample consisted of $37.2 \%$ male and $62.8 \%$ female. The marital status was $72.2 \%$ single and $27.8 \%$ marry. The average age of respondents was 31.06 with standard deviation of 5.89. Most of the respondents had a bachelor's degree (75.9\%) and had income of Baht 40,000 or lower (94.8\%). We then performed confirmatory factor analysis to examine convergent and discriminant validity by using the LISREL program. We tested the measurement model by treating all the constructs to be exogenous latent variables and allowed them to covary. All lambdas $(\lambda)$ were found to be above 0.6 with the lowest equaled 0.676 and the highest was 0.916 ; most of them were above 0.7 . All lambdas $(\lambda)$ were found to be highly significant with p-value less than 0.001. The composite reliabilities (CR) of eight constructs ranged from 0.752 to 0.930 . All were above 0.6. All the average variance extracted (AVEs) values were above 0.5 ranging from 0.503 to 0.817 . The results indicated that our constructs achieved convergence in measurement [33]. The goodness of fit indices suggested a good fit of the model. SRMR was 0.051 (less than 0.8 ) and CFI, TLI, and NFI were well above 0.90 [34]. We then tested discriminant validity by comparing squared correlation coefficient with each of the two correlated constructs' AVEs. The results indicated that all squared correlation coefficients were less than each of their individual AVEs. Thus, discriminant validity was achieved [35]. This meant our latent constructs were different from one another. We then tested our structural model shown in Figure 2 by using the LISREL program to test our proposed model.

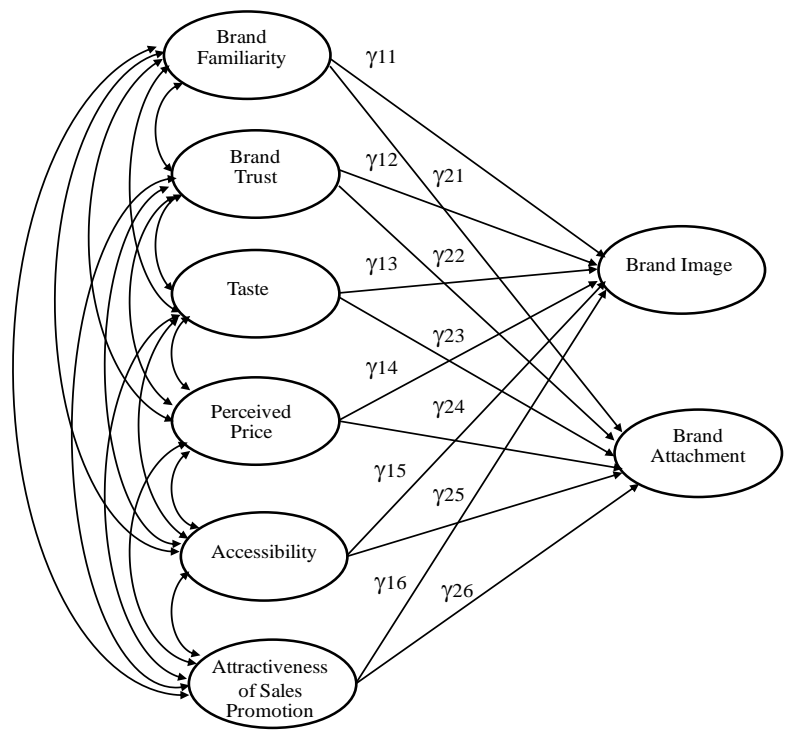

Fig. 2. The structural model for testing 
The results from the test were presented in Table I.

TABLE I: RESULTS OF THE STUDY

\begin{tabular}{|l|c|c|c|}
\hline \multicolumn{1}{|c|}{ Path } & LISREL Symbol & Coefficients & t-value \\
\hline $\begin{array}{l}\text { Brand Familiarity } \\
\rightarrow \text { Brand Image }\end{array}$ & $\gamma 11$ & 0.090 & 1.680 \\
\hline $\begin{array}{l}\text { Brand Trust } \rightarrow \\
\text { Brand Image }\end{array}$ & $\gamma 12$ & 0.470 & $8.967^{* * *}$ \\
\hline $\begin{array}{l}\text { Taste } \rightarrow \text { Brand } \\
\text { Image }\end{array}$ & $\gamma 13$ & 0.145 & $2.486^{*}$ \\
\hline $\begin{array}{l}\text { Perceived Price } \rightarrow \\
\text { Brand Image }\end{array}$ & $\gamma 14$ & -0.001 & -0.020 \\
\hline $\begin{array}{l}\text { Accessibility } \rightarrow \\
\text { Brand Image }\end{array}$ & $\gamma 15$ & 0.398 & $7.138^{* * *}$ \\
\hline $\begin{array}{l}\text { Attractiveness of } \\
\text { Sales Promotion } \rightarrow \\
\text { Brand Image }\end{array}$ & $\gamma 16$ & 0.020 & 0.483 \\
\hline $\begin{array}{l}\text { Brand Familiarity } \\
\rightarrow \text { Brand } \\
\text { Attachment }\end{array}$ & $\gamma 21$ & -0.114 & -1.828 \\
\hline $\begin{array}{l}\text { Brand Trust } \rightarrow \\
\text { Brand Attachment }\end{array}$ & $\gamma 22$ & 0.127 & $2.331^{*}$ \\
\hline $\begin{array}{l}\text { Taste } \rightarrow \text { Brand } \\
\text { Attachment }\end{array}$ & $\gamma 23$ & 0.330 & $4.822^{* * *}$ \\
\hline $\begin{array}{l}\text { Perceived Price } \rightarrow \\
\text { Brand Attachment }\end{array}$ & $\gamma 24$ & -0.074 & -1.187 \\
\hline $\begin{array}{l}\text { Accessibility } \rightarrow \\
\text { Brand Attachment }\end{array}$ & $\gamma 25$ & 0.236 & $3.856^{* * *}$ \\
\hline $\begin{array}{l}\text { Attractiveness of } \\
\text { Sales Promotion } \\
\text { Brand Attachment }\end{array}$ & $\gamma 26$ & 0.330 & $6.630^{* * *}$ \\
\hline
\end{tabular}

*** Significant at 0.001

** Significant at 0.01

* Significant at 0.05

The results from the structural model suggested that brand trust and accessibility had significant and positive effects on brand image $(\mathrm{p}>0.001)$. Taste was also found to have a significant and positive effect on brand image $(p>0.05)$. In case of brand attachment, taste, accessibility, and attractiveness of sales promotion were found to have significant and positive effects on brand attachment ( $p>0.001)$. Brand trust was also found to have a significant and positive effect on brand attachment ( $\mathrm{p}>0.05)$.

Goodness of fit indices suggested a good fit of the model. SRMR was found to be 0.0514 (less than 0.8) and CFI was 0.949 [34]. RMR was 0.0224. NFI, TLI, IFI, and RFI were all above 0.90 .

\section{DISCUSSION}

Our structural model suggested that brand trust, accessibility, and taste had significant and positive effects on brand image. Brand trust had the strongest effect, followed by accessibility, and taste. When we trust the brand, the brand image will go up. If we believe that the brand will perform what it is supposed to perform, our impression of the brand will go up. In the restaurant business where physical presence is key to success, accessibility will be an important criterion for consumers to make up their minds. Consumers will have good and positive feelings, i.e., impression, about the brand when the location of the brand is easy and convenient to access. Finally, taste of food is considered to be a very important factor in the restaurant business.

Moreover, our results suggested that taste, accessibility, attractiveness of sales promotion, and brand trust had significant and positive effects on brand attachment. Attractiveness of sales promotion had the strongest effect, followed by taste, accessibility, and brand trust. The emotional link between the brand and the consumer will be the result of good sales promotion. Good sales promotion will stimulate brand attachment. Similar to brand image, taste, accessibility, and brand trust will be the key driver of brand attachment.

Brand familiarity had no effect on both brand image and brand attachment. This is due to the fact that being familiar with the brand may not translate into consumers' impression of the brand and may also not translate into an emotional link between consumers and the brand. Perceived price also did not have an effect. This is because Japanese buffet restaurants may provide good value for the money customers have to pay. Customers can eat whatever they want and can eat as much as they can. Sales promotion had no effect on only brand image. Giving discount or other special sales promotion may not be related to the impression of the brand. Impression of the brand is one thing; good sales promotion is another thing. They are not related. Brand image itself should not have any influential effect on brand attachment. Having an impression about a brand does not translate into an emotional link between the brand and consumers. That is why we did not propose any relationship between brand image and brand attachment. The correlation between the two was also found to be low.

The contribution of this research is the connection between brand concepts and marketing strategies. The study includes brand familiarity, brand trust, brand image, and brand attachment in the conceptual framework with marketing strategies. The implication is that to create brand image and brand attachment, restaurant businesses must focus on consumer trust of the brand, the taste of their food, and the location where their restaurants are situated. In addition, it is not surprising to find that attractiveness of sales promotion only has a positive effect on brand attachment. This means that providing special discounts to the restaurant's members may be one solution to help create brand attachment. Membership and reward program may help arouse the emotional link between the restaurant and consumers. The limitation of this research is that there are still some other brand concepts, such as brand awareness, brand recognition, and brand affect, that have been left out of the study. Future research may want to examine the effects of some other elements of brand concepts.

\section{CONCLUSION}

The purpose of this study was to examine the effects of brand familiarity, brand trust, and marketing strategies consisting of taste, perceived price, accessibility, and attractiveness of sales promotion on brand image and brand attachment. The focus was on Japanese buffet restaurants. We used LISREL program to analyze the data. First, we examined the measurement model to verify convergent validity. The findings showed that all lambda $(\lambda)$ were above 0.6 . We computed composite reliability (CR) and average variance extracted (AVE). The CRs were all above 0.6 and the AVEs were all above 0.5. Convergent 
validity was achieved. Discriminant validity was also achieved because the squared correlation of the two latent constructs was lower than the AVE of each of the two latent constructs. It was true for all squared correlation coefficients. Finally, we used the structural model to test our conceptual framework. The results showed that brand trust, accessibility, and taste of food had significant and positive effects on brand image. In case of brand attachment, taste of food, accessibility, attractiveness of sales promotion, and brand trust had significant and positive effects on brand attachment. Goodness of fit indices were found to be very satisfactory. Future research may want to examine other aspects of brand concepts, such as brand awareness, brand recognition, and brand affect.

\section{REFERENCES}

[1] K. Hobkirk. (June 2019). The important differences between brands and branding. Available: https://trainofthought.net/branding/the-differences -between-brands-and-branding-355/

[2] Branding. (June 2019). Available: http://www.businessdictionary.com/ definition/branding.html

[3] P. D. Bennett, Dictionary of Marketing Terms, Chicago IL: American Marketing Association, 1988.

[4] P. Mohajerani, and A. Miremadi, "Customer satisfaction modeling in hotel industry: A case study of Kish Island in Iran," International Journal of Marketing Studies, vol. 4, no. 3, pp. 134-152, 2012. https://doi.org/10.5539/ijms.v4n3p134

[5] K. L. Keller, "Conceptualizing, measuring, and managing customer-based brand equity," Journal of Marketing, vol. 57, no. 4, pp.1-22, 1993.

[6] P. Kotler, and K. L. Keller, Marketing Management, 15th edition Harlow, U.K.: Pearson Education Limited, 2018.

[7] S. Kima, J. Y. Choeb, and J. F. Petrick, "The effect of celebrity on brand awareness, perceived quality, brand image, brand loyalty, and destination attachment to a literary festival," Journal of Destination Marketing \& Management, vol. 9, pp. 320-329, 2018. https://doi.org/10.1016/j.jdmm.2018.03.006

[8] J. Lahap, N. S. Ramli, N. M. Said, S. M. Radzi, and R. A. Zain, “A study of brand image towards customer's satisfaction in the Malaysian hotel industry," Procedia - Social and Behavioral Sciences, vol. 224, pp. 149-157, 2016.

https://doi.org/10.1016/j.sbspro.2016.05.430

[9] C. W. Park, D. J. MacInnis, J. Priester, A. B. Eisingerich, and D. Iacobucci, "Brand attachment and brand attitude strength: Conceptual and empirical differentiation of two critical brand equity drivers," Journal of Marketing, vol. 74, no. 6, pp. 1-17, November 2010. https://doi.org/10.1509/jmkg.74.6.1

[10] G. Pedeliento, D. Andreini, M. Bergamaschi, and J. Salo, "Brand and product attachment in an industrial context: The effects on brand loyalty," Industrial Marketing Management, vol. 53, pp. 194-206, 2016. https://doi.org/10.1016/j.indmarman.2015.06.007

[11] M. Thomson, D. J. MacInnis, and C. W. Park, "The ties that bind: Measuring the strength of consumers' emotional attachments to brands," Journal of Consumer Psychology, vol.15, no. 1, pp. 77-91, 2005. https://doi.org/10.1207/s15327663jcp1501_10

[12] E. Hwang, S. Baloglu, and S. Tanford, "Building loyalty through reward programs: The influence of perceptions of fairness and brand attachment," International Journal of Hospitality Management, vol. 76, pp. 19-28, 2019. https://doi.org/10.1016/j.ijhm.2018.03.009

[13] C. W. Park, D. J. MacInnis, and J. Priester, "Brand attachment: Constructs, consequences, and causes," Foundations and Trends in Marketing, vol. 1, no. 3, pp. 191-230, 2006.

https://doi.org/10.1561/1700000006
[14] M. J. Taghipourian, and M. M. Bakhsh, "Brand attachment: Affecting factors and consequences," International Journal of Engineering Research and Management, vol. 2, no. 11, pp. 5-9, November 2015.

[15] R. J. Kent, and C. T. Allen, "Competitive interference effects in consumer memory for advertising: The role of brand familiarity," Journal of Marketing, vol. 58, pp. 97-105, 1994. https://doi.org/10.1177/002224299405800307

[16] M. C. Campbell, and K. L. Keller, "Brand familiarity and advertising repetition effects," Journal of Consumer Research, vol. 30, no. 2, pp. 292-304, 2003. https://doi.org/10.1086/376800

[17] E. K. Macdonald, and B. M. Sharp, "Brand awareness effects on consumer decision making for a common, repeat purchase product: A replication," Journal of Business Research, vol. 48, no. 1, pp. 5-15, 2000. https://doi.org/10.1016/S0148-2963(98)00070-8

[18] M. Dahlen, "Banner ads through a new lens," Journal of Advertising Research, vol.41, pp. 23-30, July/August 2001. https://doi.org/10.2501/JAR-41-4-23-30

[19] Y. K. Choi, S. M. Lee, and H. Li, "Audio and visual distractions and implicit brand memory: A study of video game players," Journal of Advertising, vol. 42, no. 2-3, pp. 219-227, 2013. https://doi.org/10.1080/00913367.2013.775798

[20] M. K. J. Waiguny, M. R. Nelson, and R. Terlutter, "Entertainment matters! The relationship between challenge and persuasiveness of an advergame for children," Journal of Marketing Communications, vol. 18 , no.1, pp. 69-89, 2012. https://doi.org/10.1080/13527266.2011.620766

[21] A. Chaudhuri, and M. B. Holbrook, "The chain of effects from brand trust and brand affect to brand performance: The role of brand loyalty," Journal of Marketing, vol. 65, no.2, pp. 81-93, 2001. https://doi.org/10.1509/jmkg.65.2.81.18255

[22] T. Soedarto, G. S. A. Kurniawan, and R. J. Sunarsono, "The parceling of loyalty: Brand quality, brand affect, and brand trust effect on attitudinal loyalty and behavioral loyalty," Academy of Strategic Management Journal, vol. 18, no. 1, pp. 1-15, 2019.

[23] E. T. Kabadayi, and A. K. Alan, "Brand trust and brand affect: Their strategic importance on brand loyalty," Journal of Global Strategic Management, vol. 6, no. 1, pp. 80-88, June 2012. https://doi.org/10.20460/JGSM.2012615788

[24] V. A. Zeithaml, "Consumer perceptions of price, quality and value: A means-end model and synthesis of evidence," Journal of Marketing, vol. 52, pp. 2-22, July 1988. https://doi.org/10.1177/002224298805200302

[25] T. T. Nagle, and R. K. Holden, The Strategy and Tactics of Pricing : A Guide to Profitable Decision Making Responsibility, 3rd ed. Upper Saddle River, NJ : Prentice Hall, 2002.

[26] R. Setiawan, and A. Achyar, "Intention to buy in online store in Indonesia," Asean Marketing Journal, vol. 4, no. 1, pp. 26-36, June 2012.

[27] Y. Wang, and L. Chen, "An empirical study of the effect of perceived price on purchase intention evidence from low-cost carriers," International Journal of Business and Social Science, vol. 7, no. 4, pp. 97-107, April 2016.

[28] Why Accessibility is Key in The Retail Industry (June 2016). Available: https://www.gartec.com/2016/09/20/accessibility-key-retail-industry/

[29] M. Blut, C. Teller, and A. Floh, "Testing retail marketing-mix effects on patronage: A meta-analysis," Journal of Retailing, vol. 94, no. 2, pp. 113-135, 2018. https://doi.org/10.1016/j.jretai.2018.03.001

[30] S. Kemp. (June 2019). Promotion strategy for restaurants. Available: https://smallbusiness.chron.com/promotion-strategy-restaurants-52398. $\mathrm{html}$

[31] M. L. Lin, J. Yang, and C. Wan, "Effect of restaurant discount coupon depth on re-consumption willingness: A moderating role of brand image," Tourism and Hospitality Research, vol. 15, no. 3, pp. 193-205, April 2015. https://doi.org/10.1177/1467358415578470

[32] J. C. Nunnally, Psychometric Theory, 2nd ed., New York, NY: McGraw-Hill, 1978. 
[33] R. P. Bagozzi and Y. Yi, "On the evaluation of structural equation models," Journal of the Academy of Marketing Science, vol. 16, pp. 74-94, January 1988.

https://doi.org/10.1177/009207038801600107

[34] L. Hu, and P. Bentler, "Fit indices in covariance structure modeling: Sensitivity to underparameterized model misspecification," Psychological Methods, vol. 3, pp. 424-453, 1998. https://doi.org/10.1037//1082-989X.3.4.424

[35] C. Fornell, and D. F. Larcker, "Evaluating structural equation models with unobservable variables and measurement error," Journal of Marketing Research, vol. 18, no. 1, pp. 39-50, 1981.

https://doi.org/10.1177/002224378101800104 